\title{
THE ORGANIZATION OF DISTANCE LEARNING OF MUSIC TEACHERS IN THE CONDITIONS OF POSTGRADUATE EDUCATION REFORMING
}

\section{Kondratova 45}

\begin{abstract}
Стаття присвячена висвітленню актуальних проблем організації дистанційного навчання вчителів музичного мистецтва в період реформування та упровадження новітніх форм підвищення кваліфікації педагогічних прачівників в системі післядипломної освіти. Розглянуто сучасний досвід з організації дистанційного навчання вчителів музичного мистецтва в післядипломній освіті. Приділено увагу сучасним проблемам дистанційного навчання, описано досвід організації дистанційного етапу навчання в різних видах курсів підвищення кваліфікації, впровадження тематичних, авторських курсів для вчителів музичного мистецтва. Описуються особливості організаиії дистанційних тренінгових авторських курсів підвищення кваліфікації, демонструються переваги поглибленого тренінгового, тематичного навчання. Розглянуто інноваційні форми організації дистанційного навчання вчителів в системі післядипломної освіти. Зосереджено увагу на особливостях сучасних платформ дистанційного навчання та описано їх освітні можливості. Описано переваги використання в дистанційному навчання сучасних освітніх середовищ, форм організації освітньої діяльності вчителів. Перелічені види освітніх завдань, тестів, ичифрових матеріалів в освітньому середовищі. Описано найбільш уживані форми підготовки педагогів в дистаниійній формі навчання.

Описано досвід організації дистанційного навчання для вчителів музичного мистецтва в умовах післядипломної освіти. Розглянуто проблеми післядипломної педагогічної освіти вчителів мистечької освітньої галузі в руслі реформування та реалізації нового змісту освіти мистецької освіти. Виокремлено проблеми та потреби професійного вдосконалення вчителів музичного мистеитва, які можна вирішити в період дистанційного навчання в системі післядипломної освіти.

Описано результати досліджень в системі післядипломної педагогічної освіти, які демонструють виявлені пріоритети серед видів і форм дистанційного навчання серед вчителів музичного мистеитва. Зосереджено увагу на змістовному наповненні дистаниійного, мережевого, електронного навчання педагогів, добір ефективних технологій навчання вчителів музичного мистеитвв в післядипломній педагогічній ocвimi
\end{abstract}

Ключові слова: дистаниійне навчання, вчителі музичного мистецттва, післядипломна освіта, форми навчання, реформа

\section{Introduction}

At reforming postgraduate education the attention of many scientists is fixed to problems of implementing new learning technologies for teachers, among which a special place is given to distance education. A separate cluster of secondary education teachers, improving their qualification in postgraduate education, are ones of music art. A special feature is not only the content component of the learning module of this category of pedagogical workers, based on the specificity of art-pedagogic activity, but also learning technologies. If problems of learning technologies of music art teachers by the inclass learning form are highlighted in scientificpedagogical sources enough, ones of distance learning organization for this category of teachers need the most attention. Problems of organization peculiarities of communication, interaction, exchange of pedagogical experience by teachers at distance learning need more detail highlighting. An investigation of urgent problems of peculiarities of distance education of music art teachers allows to reveal a positive native experience in the chosen problem, platform of distance learning, effective practical working forms and the content of postgraduate teachers' education, and to outline ways and prospects of improving learning technologies under conditions of postgraduate education.

\section{Literature review}

The review of the scientific-theoretical and methodical aspect of the studied problem has revealed works of many scientists, devoted to problems of organization of distance learning in postgraduate education [1, 2]. The researchers determine high professionalism, high level of communication with colleagues, striving for cooperation, flexibility, high technology as advantages of distance learning $[3,4]$. The consideration of possibilities of postgraduate education for improving distance learning technologies is a subject of many scientists' works [5]. Problems of technologies, forms and methods of distance learning organization attract attention of many 
native researchers $[6,7]$. Foreign scientists note in distance learning the presence of accessible information sources, individualization of learning, comfortable consulting system, democratic relations between a tutor and one, who is studying, comfortable schedule and place of work and so on $[4,8]$. The foreign experience of distance learning proves the effectiveness of such learning forms as institutions of distance education and selfeducation, TV-universities, tutor centers (multimedia learning), information centers (internet-learning) and so on $[9,10]$.

It is noted in the scientists' works, that distance learning technologies are a totality of methods and means of learning and management that provide realization of the learning process at distance, based on modern information and TV-communication technologies, constantly develop and improve [11]. The problem of music art teachers' distance learning organization is still insufficiently studied, so need more profound attention from both scientists and teachers of secondary education institutions.

So, the analysis of literary sources allows to reveal that the question of music art teachers' distance learning development under conditions of postgraduate education is urgent. The elucidation of problems of technologies of music art teachers' distance learning organization and content filling allows to reveal the positive native experience and to give methodical recommendations for further use of new technologies of distance and mixed learning.

\section{The aim and objectives of the study}

The aim of the study was to ground peculiarities of music art teachers' distance learning organization under conditions of postgraduate education reforming.

To achieve this aim, the following objectives were set:

1. To determine requirements as to music art teachers' distance learning organization under conditions of postgraduate education.

2. To note problems and needs of music art teachers' professional improvement that can be solved in the period of distance learning within the system of postgraduate education.

3. To consider the modern experience of music art teachers' distance learning organization in postgraduate education.

4. To study peculiarities and educational possibilities of modern platforms of distance learning.

5. To describe the effectiveness of distance training author courses for qualification improvement and to determine advantages of profound training, thematic learning.

6. To determine ways and prospects of implementing new forms of distance learning in the system of postgraduate education.

4. Urgent problems of music art teachers' distance learning organization in postgraduate education under conditions of educational reforms

Distance learning that became very popular last time in the system of postgraduate education is defined by researchers as an interaction between a teacher and a student at distance that highlights all components, inherent to the learning process, such as: aim, content, methods, organization forms, learning means, specific means of Internet-technologies [12]. Under conditions of postgraduate education for organizing distance learning, a teacher, who is a curator-tutor, elaborates a distance course, defined by researchers as a learning activity for processing and assimilating structured information, planned by a teacher and realized, based on learning and working schedules [13]. Distance learning programs are based on the module principle, at that each separate course consists by content of several independent learning modules (topics), and a learning-thematic plan of such course consists of interrelated components: content (lectures); fixing (practice activities); controlling (tests and tasks) [14].

For organizing distance learning according to requirements, fixed in the educational professional program, a curator-tutor of the course designs a trajectory of distance learning of groups of listeners. A curator introduces webinars in the plan-schedule of the distance course, organizes chat discussion, sets an interconnection with listeners, based on mobile apps, correspondence and so on. Distance learning includes not only independent acquaintance of listeners with lecture educational materials, but also specific forms of pedagogical communication, cooperation, co-creativity. All course tasks as a certain independent practice work of listeners are directed on self-development, self-improvement, increase of the professional level of teachers and acquirement of professional, occupational competences by them.

So, advantages of distance learning, comparing with other learning forms, may be considered as high informativeness, accessibility, economy, effectiveness of the postgraduate educational activity that needs less time and energy for acquiring knowledge, is must more mobile and comfortable than other learning forms.

The specificity of art-pedagogical activity of music art teachers needs a specific content filling of a distance course and different practical working forms, able to satisfy music art teachers' professional needs in professional development.

It is known, that music art teachers in their pedagogical activity organize the art-creative activity of education applicants, their perception and appreciation of music compositions, realize communication and interaction of children, based on art. Among professional skills of music art teachers it is compulsory to master a music instrument, to have conductor skills, ones of vocal-choral work organization, elementary music playing, movements in music, staging, scenario activity and so on. Just that is why a curator-tutor must provide at distance learning of this category of pedagogical workers the use of such means and digital learning instruments that would give a possibility to realize practical tasks, connected with audio, video materials for sound-making, soundreproduction, conversion, redaction and so on.

At the same time together with the active development of digital technologies, there appeared a necessity of music art teachers' learning as to acquiring practical skills in working with digital programs in writing a music text, montage and redaction of audio-video files, mastering possibilities of web-services as to preparation of an 
audio-visual accompaniment of lessons in the art educational branch.

Taking into account the listed educational needs that must be improved by music art teachers under conditions of postgraduate education, it is necessary to consider the native experience of music art teachers' distance learning. In the period of educational reforms, implementation of ideas of the New Ukrainian school postgraduate education must satisfy teachers' needs, directed on acquiring the complex of professional competences. Conceptual bases of educational reforms determine priorities of information and media literacy, need in active development of the information-digital competence of modern teachers and need in self-development, finding of new self-education forms. At the same time implementation of the new content of music education needs from a music art teachers fast reaction to educational innovations and causes a need in selfimprovement, realized in different forms of formal, non-formal and informal education.

The native experience of "Art" teachers' distance learning proves the effectiveness of many forms and methods of teachers' postgraduate learning organization. Distance learning of teachers is organized on different platforms of distance learning with many educational possibilities.

The most spread is the module object-oriented learning environment Moodle, also named the learning management system (LMS), course management system (CMS), virtual learning environment (VLE) or simply the learning platform. This distance platform gives teachers a developed set of instruments for learning, among which: modules "Activity types" include a possibility to create tasks for appraisement, to organize communication in a forum or chat, testing, realization of tasks, providing downloading files with work results, presentation of elements for joint work; modules "Resource" allow to add any content to a course (text and web-pages, inscriptions, references on files, catalogues and so on) [15].

The distance platform Mobi-school provides support organization for all functions of the educational process (managerial, learning, upbringing), it is completely adapted to present conditions of education informatization, contains web-instruments for creating, implementing the authentic e-environment of an educational institution and allows to support the educational process by a chat, learning materials, WEB -libraries and video-chat [16].

For conducting webinars and online conferences, platforms Zoom, Webek, platforms from Google Google Hangouts, Google Meet; platform from Microsoft 365 Skype and Teams became widespread.

As it is proved by the native experience of distance learning, Google Classroom educational environment is rather comfortable and effective for organizing qualification improvement courses. Thus, during two years two All-Ukrainian distance learning courses for teachers of art disciplines were organized with the support of the publishing house Learning book-Bogdan (Ternopil), based on the Google Classroom environment. The first distance course gave a possibility to consider methodical aspects of teaching art disciplines and im- proving pedagogical mastership, and the other one gave a possibility to master digital technologies in teaching art. Forms of cooperation and interaction, based on digital instruments and Google redactors (documents, tables, presentations), preparation of creative tasks, presented at interactive Padlet, Jambord from Google and experience exchange, discussion of achievements in joint reflections were actively used in distance learning [17].

Qualification improvement of music art teachers in the distance learning form, realized based on problem, author and thematic courses, gives more significant results. An example of author and thematic courses may be learning, connected with preparing teachers for implementing new content of art education in the period of educational reforms, for organizing art-creative, playing activity of school children, mastering new technologies in teaching art and so on. Advantages of distance learning at author thematic courses are: profound learning of themes, orientation on practical mastering of theoretical knowledge, acquiring practical knowledge and skills in mastering innovative studying technologies, familiarization of the experience of using an offered topic in the practice of pedagogical activity and so on.

In the period of educational reforms an important aspect is determination of ways and prospects of implementing new forms of distance learning in the system of postgraduate education. Further improvement in music art teachers' distance learning is needed by problems of profound mastering digital technologies by them, training for using interactive digital means in music art teaching, mastering web-resources for preparing audio-visual learning means and so on.

So, considering urgent problems of music art teachers' distance learning organization in postgraduate education under conditions of educational reforms, we must note the need in further development and improvement of distance education for teachers of secondary educational institutions. Among development prospects of music art teachers' distance education we must note the search for new platforms and web-resources for organizing web-conferences, webinars, finding new ways for presenting lecture activities, pedagogical experience, wider use of network communication and interaction between listeners of courses, wide use of e-learning means. Additional efforts are needed for determining the content filling of distance learning, improvement of programs of author, problem, thematic courses, using mixed learning technologies, choice of actual learning topics, directed on satisfaction of educational needs of teachers from the art branch, formation of a bank of innovative forms and methods for teaching art and so on.

\section{Research results}

At analyzing the sources, it has been revealed, that teachers' distance learning is considered as: interaction between teachers and a curator-tutor at distance that highlights all components, inherent to the learning process, such as: aim, content, methods, organization forms, learning means, specific means of Internet-technologies The study of urgent problems of music art teachers' distance learning organization in postgraduate education under conditions of educational reforms allowed to reveal innovation tendencies in distance learning and to 
outline ways and prospects of the chosen problem. Conclusions, obtained as a result of the work, don't pretend to be an exhaustive solution of the problem of music art teachers' distance learning organization in postgraduate education under conditions of educational reforms. The work may be continued in the direction of studying problems of content filling of distance learning, improving programs of author problem thematic courses, using mixed learning technologies at training music art teachers under conditions of postgraduate education.

\section{Conclusions}

So, the problem of music art teachers' distance learning organization in postgraduate education under conditions of educational reforms is rather urgent. The study of urgent problems of music art teachers' distance learning organization in postgraduate education under conditions of educational reforms allowed to make the following conclusions:

1. The determination of problem of requirements as to music art teachers' distance learning organization under conditions of postgraduate education allowed to reveal advantages of distance learning, comparing with other learning forms, that may be considered as high informativeness, accessibility, economy, effectiveness of the postgraduate educational activity that needs less time and energy for acquiring knowledge, is must more mobile and comfortable than other learning forms.

2. The study of problems and needs of music art teachers' professional improvement that can be solved in the period of distance learning in the system of postgraduate education has revealed that the specificity of music-pedagogical activity of music art teachers must provide the use of new means and digital learning instruments for improving work with audio, video materials for sound-making, sound-reproduction, conversion, redaction, acquiring practical skills in working with digital programs in writing a music text, montage and redaction of audio-video files, mastering of possibilities of web-services as to preparation of an audio-visual accompaniment of lessons in the art educational branch and so on.
3. The consideration of the modern experience of music art teachers' distance learning organization in postgraduate education has revealed the positive experience of using problem, author and thematic courses at distance learning, at which the forms of cooperation and interaction, based on digital instruments and Google redactors (documents, tables, presentations), preparation of creative tasks, presented at interactive Padlet, Jambord from Google and experience exchange, discussion of achievements in joint reflections, were actively used.

4. The study of peculiarities and educational possibilities of modern platforms of distance learning has revealed that the learning environment Moodle with the developed set of instruments for learning, distance platform Mobi-school that provides support organization for all functions of the educational process and is adapted to present conditions of education informatization with the developed set of web-instruments; wide spectrum of platforms for conducting webinars and online conferences: Zoom, Webek, platform from Google - Google Hangouts, Google Meet; platform from Microsoft 365 Skype and Teams and the effective educational environment Google Classroom are most spread in teachers' distance learning.

5. The study of problems of the effectiveness of distance author courses for qualification improvement allowed to determine the advantages of profound training thematic learning, including: profound learning of themes, orientation on practical mastering of all theoretical knowledge, acquiring practical abilities and skills in mastering innovative studying technologies, familiarization of the experience of using an offered topic in the practice of pedagogical activity and so on.

6 . The study of the problem of distance learning allowed to reveal ways and prospects of implementing new forms of distance learning in the system of postgraduate education, among which there are: the search for new platforms and web-resources for organizing webconferences, webinars, finding new ways for presenting lecture activities, pedagogical experience, wider use of network communication and interaction between listeners of courses, wide use of e-learning means.

\section{References}

1. Orhanizatsiia osvitnoho protsesu v zakladakh pisliadyplomnoi pedahohichnoi osvity z vykorystanniam elektronnykh tekhnolohii navchannia: handbook / ed. by Liakhotska L. L. Kyiv, 2017. 198 p.

2. Bykov V., Leshchenko M. Digital humanistic pedagogy of open education summary // Teoriia i praktyka upravlinnia sotsialnymy systemamy. 2016. Issue 4. P. 115-130.

3. Bykov V. Yu. Knowledge society and Education 4.0 // Edukacja dla przyszłości w świetle wyzwań XXI wieku. 2017. Vol. 1, Issue 1. P. 30-45. URL: http://lib.iitta.gov.ua/id/eprint/708567

4. Teoriia ta praktyka zmishanoho navchannia: monograph / Kukharenko V. M., Berezenska S. M., Buhaichuk K. L., Oliinyk N. Yu., Oliinyk T. O., Rybalko O. V. et. al.; ed. by Kukharenko V. M. Kharkiv: KhPI, 2016. 284 p.

5. Bykov V. Yu. Dystantsiine navchannia v krainakh Yevropy ta SShA i perspektyvy dlia Ukrainy // Informatsiine zabezpechennia navchalno-vykhovnoho protsesu: innovatsiini zasoby i tekhnolohii. Kyiv: Atika, 2015. P. 77-140.

6. Bazeliuk O. Zmist i struktura tsyfrovoi kultury pedahohichnykh pratsivnykiv zakladiv profesiinoi osvity // Profesiina pedahohika. 2018. Issue 16. P. 81-87.

7. Tekhnolohii dystantsiinoho profesiinoho navchannia: handbook / Bazeliuk O. V., Spirin O. M., Petrenko L. M., Kalenskyi A. A. et. al. Zhytomyr: «Polissia», 2018. 160 p.

8. Quendler E., Lamb M. Learning as a lifelong process - meeting the challenges of the changing employability landscape: competences, skills and knowledge for sustainable development // International Journal of Continuing Engineering Education and Life-Long Learning. 2016. Vol. 26, Issue 3. P. 273-293. doi: http://doi.org/10.1504/ijceell.2016.078447

9. Gaspar H. 5 Ways To Boost Conversions With Dynamic Content. URL: https://blog.kissmetrics.com/boost-conversionswith-dynamic-content/ 
10. Designer and Instructor Tutorials. Exploring WebCT Campus Edition 6.0. URL: http://etcdata.tctc.edu/VPAA /Instructional_Support/ReadyToDelete/ResourceCenter/r\%20center/WebCTCE600_Design_Instruct_ref_2005_07_18.pdf

11. Aerial-Ground Collaborative Pathfinding with HLSTL using FPGAs / Abaldea M. J., Barba J., Caba J., Escolar S., de la Torre J. A., Rincon F., Lopez J. C. // 2019 XXXIV Conference on Design of Circuits and Integrated Systems (DCIS). 2019. doi: http://doi.org/10.1109/dcis201949030.2019.8959919

12. Kukharenko V. M. Systemnyi pidkhid do zmishanoho navchannia // Informatsiini tekhnolohii v osviti. 2015. Issue 24. P. $53-67$.

13. Bykov V. Yu. Project approach and distance learning in professional management training: proceeding // Krymski pedahohichni chytannia. 2001. P. 30-50.

14. Metodychni rekomendatsii do rozroblennia elektronnoho navchalnoho kursu: textbook. Kyiv, 2015. 36 p.

15. Kartashova L. A., Bakhmat N. V., Plish I. V. Rozvytok tsyfrovo kompetentnosti pedahoha v informatsiino-osvitnomu seredovyshchi zakladu zahalnoi serednoi osvity // Informatsiini tekhnolohii i zasoby navchannia. 2018. Vol. 68, Issue 6. P. $193-195$.

16. Polozhennia pro dystantsiine navchannia: Nakaz Ministerstva osvity i nauky Ukrainy No. 40. 21.01.2004. URL: http://zakon4.rada.gov.ua/laws/show/z0703-13\#n18

17. Kondratova L. Distance courses "Methodology of teaching art in primary school based on principles of the New Ukrainian School" as a means of professional self-development of an art teacher // Art and Education. 2019. Vol. 3. P. 50-53. doi: http://doi.org/10.32405/2308-8885-2019-3-50-53

Received date 01.05.2020

Accepted date 03.06.2020

Published date 31.07.2020

Lyudmila Kondratova, PhD, Associate Professor, Department of Integrated Systems and Information Technologies and Technologies, tate Higher Educational Institution "University of Management" of the National Academy of Pedagogical Sciences of Ukraine, Sichovykh Striltsiv str., 52 A, Kyiv, Ukraine, 04053

E-mail: rector@umo.edu.ua 